\title{
Making sense of the GATS debate: semiotic analysis of the conflicting ideas on the education/free-trade relationship
}

Antoni Verger. Universitat Autònoma de Barcelona

[antoni.verger@uab.cat]

\section{Introduction}

The General Agreement on Trade in Services (GATS), the agreement of the World Trade Organization (WTO) focusing on the liberalization of services, has generated an intense and passionate debate in the education field (Birtwistle 2006, Williams 2003). The main objective of the GATS is 'to establish a multilateral framework of principles and rules for trade in services with a view to the expansion of such trade under conditions of transparency and progressive liberalization' (WTO 1994: 305). Education is one of the twelve services sectors covered by the GATS and its commercial liberalization will imply the elimination of state regulatory barriers to cross-border e-learning initiatives, the establishment of branch campuses, the international takeover of schools and universities, the transaction of international students, lecturers and researchers, and so on. Currently, the 155 member countries of the WTO are negotiating the further liberalization of their education systems in the context of the Doha Round (2001-ongoing). Within this negotiations' round, very few themes have generated such a controversy as education has done (Saner 2008).

To a great extent, the GATS is so controversial due to the fact that education is traditionally conceived as a public good and the trade agreement challenges the 
conventional frameworks, rationales and instruments through which this good is governed and delivered to citizens by the state. The GATS contributes to generate a regulatory framework that is friendly to private provision and to private investment in education. In this sense, the penetration of GATS in the education field has fuelled and given an international dimension to the wider privatization debate that has been going-on for decades at the national level (see Ball 2007, Maroy 2008). Furthermore, the GATS endorses the constitution of an increasingly liberalized education market at a world scale and promotes the intensification of international trade flows in education services, which are issues perceived as especially sensitive in developing contexts (Altbach 2002).

This article explores in detail the debate emerged around the relationship between GATS and education in the context of the WTO Doha Round. Its objective is two-fold. First, it aims at identifying and systematizing the core axes of the debate, and the confronting ideas and meaning repertoires within each of the axes. ${ }^{1}$ This systematization of ideas has an especial value due to the technical complexities of the GATS, as a legal text, and to the high number of arguments, of a very different nature, being raised both in favor and against the agreement. Second, the article aims at analyzing the semiotics of the 'GATS and education' debate. In particular, it aims at understanding how and by whom this debate is being formed and why the WTO agreement on services has generated such an intense and polarized discussion in the educational field.

To achieve these objectives, this article is structured into four main sections. The first one develops the methodological strategy, which is based on Fairclough's semiotic analysis approach, usually known as critical discourse analysis (CDA). This

\footnotetext{
${ }^{1}$ Meaning repertoires are defined as patterns of explanation that emerge within the processes of production of meaning and become key elements for actors, both individual and collective, seeking to understand the world and assign a meaning to reality (Parker 1992).
} 
framework suggests that discourse analysis should proceed at different levels, which are intimately interlinked: discursive practices, texts and contexts. The following two sections focus on the prevailing 'discursive practices' within the GATS and education debate. Specifically, the second section systematizes the main explanatory discourses that exist within the debate (i.e. identification of problems and their causes, cost and benefit analyses of the GATS effects in education systems, etc.) whilst the third one systematizes the prognostic discourses (i.e. recommendations on how to address the issues perceived as problematic). The last section of the article analyses the meaning repertoires identified in the previous parts by appealing to, on the one hand, the main linguistic patterns and rhetoric figures prevailing in the debate ('text') and, on the other, the broader institutional and ideational frameworks in which the debate is inscribed ('text in context').

\section{Methodology}

Discourse analysis has gained centrality in educational research over the last decades (Rogers et al. 2005). However, 'discourse analysis' is far from representing a specific and coherent methodological corpus. There are many different methodological approaches to 'discourse analysis', including those that, at one extreme, pay close attention to the linguistic features of texts and those that, at another extreme, focus on the wider context of texts and, by doing so, pay little attention to the linguistic features of texts (Taylor 2004). The methodological strategy of this article is specifically grounded on critical discourse analysis (CDA) that, as I develop below, has the value of integrating different levels of analysis, from texts to contexts, in a coherent analytical framework. 
CDA is a research approach that focuses on semiosis, i.e. the production of intersubjective meaning, as an entry point to the study of reality and social, political and economic change (Fairclough, Jessop and Sayer 2004). CDA understands that semiosis is a mode of action with constitutive powers, but, at the same time, as something that is socially constituted in the sense that internalizes social relations, cultural values and institutional norms (Fairclough 2003).

CDA integrates different levels of analysis in a coherent analytical framework. According to Fairclough (2003), these levels, from the micro to the macro, are: a) discourse as text, which focuses on the linguistic features and rhetoric figures of texts; b) discourse as discursive practice, which looks at the socio-cognitive aspects and causal ideas involved in the production and distribution of texts; c) discourse as social practice, which focuses on the power, institutional and ideational relations that are external to the text, but actually reflected in it. Our analysis of the GATS and education debate covers these three levels of analysis. Specifically, CDA allows us to, first, identify the main meaning repertoires of the debate, second, analyze the rhetoric strategies of the actors involved in the debate and the properties of their ideas (consistency, empirical credibility, bias, etc.) and, third, to inquire the social, discursive and institutional orders affecting the content and form of the debate.

The 'GATS and education' debate has materialized in public events where the implications of the trade agreement have been discussed from different points of view. I refer, for instance, to the OECD Forums on trade in education services, the panels on education and culture organized in the context of the WTO annual public symposiums, the UNESCO Forums on International Quality Assurance, etc. However, the debate has also crystallized in a very extensive literature coming from the academic and practitioner worlds. This article has benefited from observation in 
public debates such as the WTO Public Symposium celebrated in Geneva in 2005, the $6^{\text {th }}$ WTO Ministerial Conference (Hong Kong, 2005) and the UNESCO/EI Seminar on GATS and education (Paris, 2004), although the bulk of the analysis is grounded on written texts on GATS and education that have been published in very different sources, including academic journals, reports, newsletters and websites produced by international organizations, scholars, education stakeholders and civil society groups. The corpus of the research consisted of a total of 86 documents that deal with the topic from a normative and/or 'costs and benefits' perspective. Within this sample of documents, the most referred articles on "GATS" \& "education" in the ERIC and Scholar Google databases can be found. ${ }^{2}$

The GATS affects all levels of education, from primary to adult education. However, the GATS debate is more pushing in the higher education field. This is the consequence of higher education being the education level most affected by transnationalization, trade and commodification dynamics. Thus, an important part of the documentation analyzed deals more specifically with the effects of GATS in higher education.

\section{Explanatory dimension: debating how the GATS affects education}

The main themes that are being discussed within the 'GATS and education' debate from an explanatory perspective are: a) national sovereignty; b) international development; c) education access; and d) education quality. As will be shown below, each of these themes is addressed from two meaning repertoires: one is critical with

\footnotetext{
${ }^{2}$ In this article, not all the documents in the corpus are quoted. The complete list can be downloaded from: http://educationanddevelopment.files.wordpress.com/2011/06/isse_list-of-documents.pdf
} 
respect to the implications of the GATS for education, while the other provides a positive interpretation of the potential effects of the agreement.

\section{National sovereignty}

According to Gilpin (1987), one of the key issues of international political economy is the persistent clash between the increasingly interdependent and liberalized international economy and the efforts of the states to maintain economic independence and political autonomy. States, including free-trade proponents, are often forced to manage this contradiction since they know that promoting trade liberalization means having to give up some of their political autonomy. This tension is particularly relevant to the GATS negotiations because liberalization may mean the modification or elimination of a range of regulations affecting the services sectors in question, as well as setting limits on the ability of the states to bring in new regulations. Within the WTO negotiators commercial jargon, this sovereignty tension is usually known as the "policy space" dilemma.

\section{a) Policy space restriction}

GATS critics emphasize that the trade agreement drastically restricts ability of the states to regulate education and, in particular, to promote social and equity policies within the education field (Grieshaber-Otto and Sanger 2002).

The GATS article that raises major concerns within such critical literature is that on domestic regulation (Article VI of the agreement), which basically establishes that member countries regulations must not block the "benefits derived from the GATS" and must be "the least burdensome possible" for trade. By some accounts, this article is especially intrusive in several areas of education regulation of states, such as the 
technical standards and the qualifications that are required to license new education providers. Education International (EI), the biggest international federation of teachers unions, has been one of the first agents to denounce the potential implications of the forthcoming disciplines for state education policy. EI states that, among other consequences, accepting the WTO "requiring all regulations to be the least burdensome would limit both the content and the process for democratic decisionmaking" (EI 2006, 4).

Other observers focus on the potential implications of Article VII of the GATS concerning recognition (which asks the WTO members to recognize the academic qualifications of service providers coming from other countries, and urges them to do not use these qualifications to fulfill protectionist ends). Van Ginkel and Rodrigues Dias (2006) maintain that Article VII may mean going back to an old-fashioned system of equivalencies, which establishes that those university programs that aim to be recognized may be based on an identical content and structure, independently of the context where they are issued. They are also concerned with the fact that the equivalency standards that the GATS goes for could set out minimum requirements, thus fostering mediocrity rather than excellence. Regional university associations have raised a similar concern; in particular, they belief that GATS could contravene regional recognition agreements established within the framework of UNESCO (EUA 2002).

The WTO's powerful dispute settlement system and other disciplinary mechanisms that integrate the organization, such as the necessity tests, are also called into question because of their interference in states' regulatory capacity. Necessity tests are a focus of ongoing debate in the WTO because, if accepted by members, they will mean that a country with regulations that are considered too restrictive for trade 
will have to demonstrate that they are absolutely necessary to achieve a legitimate objective such as the maintenance of the education system. (Devidal 2004)

A final issue of concern in the policy space debate relates to the GATS ability to fix and block the liberalization commitments undertaken by countries. These commitments, once established, are very difficult to withdraw because, among other reasons, the members affected by the modification may file a lawsuit and, most probably, the country modifying its commitments will have to compensate them. This means that, after adopting liberalization commitments under the GATS, a specific government trade strategy could become a permanent state policy (Fredriksson 2004).

\section{b) GATS upholds regulatory capacity of countries}

In various occasions, the WTO itself has rejected the above-mentioned criticisms on policy space by arguing that member countries liberalization commitments within the GATS “do not affect governments" right to set levels of quality, safety, or price, or to introduce regulations to pursue any other policy objective they see fit." (WTO 2001,

GATS advocates usually refer to the preamble of the agreement, where "the rights to regulate in order to meet national policy objectives are recognized explicitly" (Larsen, Martin, and Morris 2002, 863), to justify their skepticism with respect to the policy space restrictions of GATS. Specifically, this preamble says that GATS recognizes the "right of Members to regulate, and to introduce new regulations, on the supply of services within their territories in order to meet national policy objectives and, given asymmetries existing with respect to the degree of development of services regulations in different countries, the particular need of developing countries to 
exercise this right." (WTO 1994: 285)

Other pro-GATS scholars go one step further and assert that concerns over regulatory capacity implications are based on misunderstandings (Chanda 2003, Saner and Fasel 2003). Most of the time, these authors argue that countries are free to decide whether they want to make liberalization commitments in the context of the WTO negotiations. To them, if the GATS limits countries' regulatory capacity in certain aspects it is because the countries themselves have accepted it voluntarily and because they believe that education liberalization will benefit them in some sense.

It is certainly true that, as with any other legally bound undertaking in the WTO (or any other international treaty), the GATS can affect the regulatory conduct of member countries. Yet countries accept such disciplines because they deem them necessary to reaping the full benefits from international cooperation in a rules-based system. The GATS affords WTO members considerable flexibility in this regard. (Sauvé 2002, 16)

In a very similar line, some WTO members consider that the GATS can be used as a state policy to improve the state's ownership and planning capacity over the education system. This is, for instance, the case of New Zealand:

The reduction of barriers to trade in education does not equate to an erosion of core public education systems and standards. An international trade in education services can provide a means of supplementing and supporting national education policy objectives. For example, in New Zealand's experience it can help reduce the infrastructural commitments required of governments, and so free resources to be concentrated in other aspects of education policy. (WTO-NZ 2001) 


\section{GATS and development}

Development concerns have been at the forefront of the GATS education debate. The fact that education is a strategic asset for social and economic development in lowincome countries has added fuel to the free trade and education controversy.

\section{a) The unequal exchange in education}

Critics warn that the GATS will exacerbate global inequalities in the education domain. The world's centers of production and distribution of knowledge, as well as the main transnational education corporations, are mainly located in rich countries. Consequently, in a context of expanded global liberalization, developing countries will become increasingly passive receptors of education trade flows:

If educational borders are completely open, the strongest and wealthiest education providers will have unrestricted access. Countries and institutions that cannot compete will find it difficult to flourish. This means that developing countries and smaller industrialized nations will be at a considerable disadvantage. Local academic institutions will find it difficult to compete with providers that choose to set up institutions in their country. (Altbach 2002, 5)

The comparative advantage of Western countries in the education sector could affect developing education systems in various ways. Firstly, it could jeopardize the development of domestic education institutions because transnational providers would be able to dominate the education supply chain (EI and PSI 1999), or because local institutions might be taken over by transnational competitors (Aboites 2004). Secondly, the trend towards a Western-driven homogenization of education 
curriculum, languages and cultural codes could be intensified (Altbach 2004, Robertson et al 2002). A third potential impact of a global education scenario governed by GATS rules would be the intensification of the brain drain problem in the education sector.

Since many teachers and researchers want to move to countries with more favorable working conditions and salaries, there is real concern that the mostdeveloped countries will benefit from this mobility of education workers. (Anandakrishnan 2004, 19)

Another group of scholars have pointed out that the GATS could exacerbate the education regulatory weaknesses in developing countries. In these countries, education regulatory frameworks are usually less robust; therefore, their governments could face difficulties in seeking to control foreign education provider activities, quality standards or the duration of foreign investment in education (García-Guadilla 2003). This regulatory vulnerability could lead to the proliferation of low-quality educational services, primarily affecting the most vulnerable students (Pillay 2003). Moreover, if the education business is not as profitable as expected in developing countries, foreign providers will relocate, leave the country and renege on their commitments to local students (Bhushan 2006).

Some other scholars consider that the GATS could make it difficult for developing countries to use education as a policy tool for economic development and nation building in low-income nations, in the way rich countries have been using it for decades.

Through GATS, education becomes a goal rather than a means in the process of capital accumulation. Although the goals and the means of the economic 
functions of education are not necessarily mutually exclusive, those aspects that may guide the expansion of education in the search of consumers may contradict those that guide education as an area of strategic investment for economic development. (Robertson et al 2002, 493)

Finally, some university associations are concerned about the fact that the GATS could undermine the traditional dynamics of international cooperation and cultural exchange between universities, and put competition, income generation and other economic interests and values at the center of the international relations undertaken in the higher education field (AUCC et al. 2001).

\section{b) The GATS favors education in development contexts}

The GATS preamble states that the Agreement seeks "to facilitate the increasing participation of developing countries in trade in services and the expansion of their service exports including, inter alia, through the strengthening of their domestic services capacity and its efficiency and competitiveness" (WTO 1994: 285). This statement, together with the above-mentioned liberalization flexibilities allowed by GATS, has led some authors to conclude that the GATS is the most "developmentfriendly” agreement of all the Uruguay Round treaties (Sauvé 2002, 3).

Along this line, others argue that the GATS could lead to improvements in the education systems in low-income countries for various reasons. Firstly, the agreement could generate a more conductive regulatory environment to foreign investment in education and, consequently, could free governments in developing countries from having to invest public funds in higher education. This way, they could assign their limited budgets to basic education (Pillay 2003, Sanyal and Michaela Martin 2005). 
Secondly, the increase of trade in education flows by allowing foreign universities opening branch campuses abroad will reduce the risk of brain-drain because students will be able to study at a "foreign" university without actually having to go abroad (Larsen and Vincent-Lancrin 2002). Thirdly, developing countries will count on a broader education offer and will attract foreign expertise to their territories; consequently, they will accumulate higher-quality human capital, enabling them to meet the challenges of the knowledge economy (OECD and World Bank 2007). Accordingly to Bashir $(2007,80)$ in a working paper edited by the World Bank:

Reform of public universities may be difficult to introduce or sustain without external pressures. Creating a new domestic institution, public or private, that can bring in international best practice in curricula, teaching methods, research, governance and financing is often not possible with domestic resources alone. Branch campuses or the creation of international universities in partnership with foreign universities are options that can have considerable spill-over effects.

\section{Access and rights to education}

The third axis of the debate concerns the tension between education as a tradable private good and education as a basic human right. GATS critics maintain that the trade agreement could jeopardize the idea of education as a human right and contribute to increase education inequalities. However, GATS supporters maintain that the Agreement could improve education opportunities around the world.

a) GATS privatizes education 
Private-sector education providers are often profit-oriented. Consequently, if the state does not force or encourage them, they will not attempt to achieve social objectives of their own accord. According to the critical literature, the GATS will alter the balance between private and public interests in favor of the former because it limits state regulatory capacity to promote the public interest. Furthermore, the GATS seeks to ensure that education supply and demand are regulated according to market criteria, which makes it difficult for the states to conceive and promote education as a public good. ${ }^{3}$

GATS considers government monopolies to be a barrier to service trade. Many nations have systems of higher education that are largely, if not exclusively, a governmental function. Strict adherence to the principles of full service liberalization could make abandoning governmental monopolies of higher education an imperative, leading the way to substantial privatization and withdrawal of government support from public institutions. (NEA 2004, 28)

The GATS only guarantees the rights of transnational service providers (Kelsey 2003) whereas the right to education and other basic human rights are completely ignored (Devidal 2004, Tomasevski 2005). Fredriksson (2004) finds it ironic that if a child lacks access to education - even though education is considered a basic human right - there is nowhere for that child to seek redress. However, if the education industry faces trading barriers, the GATS will provide the legal right to seek and receive compensations.

The GATS could also affect public funding of education. The 'National Treatment' commitments within this agreement mean that international and national

\footnotetext{
${ }^{3}$ A public good should have two key constitutive principles, which are non-rivalry (i.e. increased consumption of educational services by one individual does not reduce accessibility or opportunities for another) and non-excludability (nobody can be denied access to the service) (Menashy 2007)
} 
education providers will benefit from the same regime of subsidies. ${ }^{4}$ These regulations could generate a sort of magnet effect, both for foreign providers and foreign students, thereby pressuring states to cut the level of public subsidies for education (Knight 2007).

Other negative implications of having GATS rules governing education systems include a drain on resources for research areas and teaching programmes with lower market demand (Scherrer 2007), education inequalities increase (Devidal 2004) and reduced capacity for states to implement affirmative action policies aimed at improving access to education for minorities or disadvantaged groups. In fact, the latter made the South African education minister himself to publicly state his opposition to GATS (Santos 2004).

\section{b) Increased supply and investment}

GATS supporters refute the idea of conceiving the agreement as a privatization device. Again, the text of the agreement itself becomes the main source for denying that it forces countries to privatize or cut public expenditure on education:

Governmental services are explicitly carved out of the agreement and there is nothing in GATS that forces a government to privatize service industries. In fact the word "privatize" does not even appear in GATS. Nor does it outlaw government or even private monopolies. (WTO 2001, 35)

As with previous issues, some react to the critics concerning the privatization problem by referring to the flexibility of the Agreement (WTO 2002). In the words of the OECD-CERI researchers, Larsen and Vincent-Lancrin (2002: 21):

\footnotetext{
${ }^{4}$ Specifically, the National Treatment principle says that foreign companies will benefit from a treatment that is no less favorable than that received by national companies from the host country.
} 
The second reason why the GATS does not jeopardize the public funding of higher education is more fundamental: countries are free to lay down as many restrictions as they wish with regard to the liberalization of a service sector. So nothing can compel a country to finance domestic and international students and institutions in a non-discriminatory way if it does not wish and is not committed to do so.

Some pro-GATS scholars maintain that the trade agreement opens opportunities for improving access to education systems around the world. The transnational education industry and the GATS can help to solve problems in contexts with overcrowded public education or where education is elitist and exclusive, especially in low-income countries (Francois and Wooton 2000). The elimination of trade barriers and the previsibility guaranteed by the GATS could combine to create a favorable environment for the foreign investment of private education companies (Mattoo and Rathindran 2001) and, this way, provide students in all countries with access to a wider education offer (WTO-Australia, 2001).

Moreover, the increasing trade flows in education under modalities such as elearning or international branch campuses can democratize access to international education. This is due to the fact that it is cheaper for poor families to send their children to foreign universities settled in their own country or to subscribe them to an on-line course than to sending them to study abroad.

Emerging nations, together with marginalized communities who have been excluded routinely from the benefits of higher education can achieve the most rapid gains from the global liberalization of the sector. Just think of detained juveniles in Malaysia who can now enroll in distance learning by universities, 
sit for tests by mail and be paroled early; or Native Americans who can take classes on their reservations; or any conditions in developing countries where culture or costs have constrained higher learning. (Czinkota 2006, 158).

Finally, GATS advocates belief that liberalization would favor new providers stepping in the education system and tuition fees would go down as a consequence of the competition increase. This way, education would become more accessible, for both governments and families (Larsen and Vincent-Lancrin 2002).

\section{Education quality}

In the global education agenda, there is an increasing awareness about the fact that low-quality educational services will not provide the expected learning outcomes and will have serious implications for students' future professional careers and for countries development strategies. The explosion of new degrees offered by foreign or on-line providers on an international scale and, in particular, the emerging regulatory role of the GATS in this area have raised new concerns over education quality and have fuelled debate over new challenges with respect to quality assurance.

\section{a) GATS damages education quality}

GATS critics consider that the Agreement, together with the specific model of education transnationalization that it promotes, jeopardizes education quality for several reasons. First, because service providers that aim to be competitive in the global education market will be pushed to become more and more efficient and rationalize their resources (Kelsey 2003). Efficiency may affect negatively education 
quality if it means paying teachers poorly, obsolete technology, or substandard libraries and laboratories.

Secondly, the liberalization promoted by the GATS could undermine government efforts to control the quality of new international or virtual education providers. A significant number of countries, primarily in the developing world, do not count on an adequate regulatory framework to assess and control education quality. In general, the number of substandard education providers (also known as diploma mills) has increased drastically in recent years in developing contexts, more noticeably in the area of virtual education (Brown 2005). Thanks to the legal environment generated by the GATS, virtual education providers could enjoy of more freedom of movement and, consequently, the quality of the services they deliver could become more difficult to control (Garrett 2005).

Another way the GATS could undermine education quality is by affecting academic freedom. Some scholars are afraid that academic freedom could be subordinated to commercial criteria and to the shifting education demands and preferences of consumers.

Under pressure from the market, private for-profit institutions specializing in higher education might have to teach or give credit to false theories merely on the grounds that such instruction is in demand (...). An economy drive might also lead to course standardization, undermining academic freedom. (Larsen and Vincent-Lancrin, 2002: 26)

The GATS does not turn a blind eye to quality assurance issues; instead, it deals directly with them, although in a way that has upset the education community. Again, the critics object to Article VI on Domestic Regulation that it could establish that 
certain quality standards and regulations are "more burdensome than necessary" for international trade. Thus, paradoxically, instead of setting minimum requirements of education quality, the agreement would be setting maximum requirements. Consequently, the GATS would be contributing to the international harmonization of quality, albeit downward (van Ginkel and Rodrigues Dias 2006, Knight, 2007).

\section{b) GATS favors quality}

In relation to the education quality debate, GATS defenders invoke the liberal theory of trade. According to this theory, the liberalization of the sector and the resulting competition will benefit education quality in different ways. First, since service quality is a source of comparative advantage for education providers, they will have to invest in quality education- including the facilities, libraries, etc. - in order to attract clients/students and to remain profitable (Larsen and Vincent-Lancrin, 2002: 24). Second, low-quality educational services will be spurned, so they will have fewer benefits and resources to invest and will eventually be driven out of the education market. And third, open markets and competitiveness contribute to the innovation and modernization of education services, and to the attraction of expertise and technical skills in the sector (Poblano 2004). The following quotation perfectly shows the existing chain of assumptions in the liberal trade theory on how the GATS could booster education quality:

The application of GATS rules to international ventures of higher education proposes an environment covered and protected by international rules and reduces the risk for investors. In consequence, there can be more investment, which leads to more competition, which gives a boost to productivity. In 
addition, rate of return expectations can be lowered, which makes it far easier to build international education capacity. (Czinkota 2006: 150)

\section{Prognostic dimension: from alternatives to continuity}

At the prognostic level, three repertoires have been identified: the first pushes for farreaching alternatives to the GATS, the second proposes reforms within the GATS system of rules and the third suggests maintaining the status quo.

\section{a) Alternatives}

A number of education stakeholders believe that education should be excluded from the GATS negotiations. This view has been expressed in numerous statements issued by international civil society organizations and teachers unions in the context of campaigns such as "Stop the GATS attack" or "Take education out of GATS" (Verger and Bonal 2009). These actors maintain that education issues such as internationalization, recognition of qualifications, quality standards, etc. should not be addressed in a trade forum. Instead, they should be dealt within international forums with more expertise and legitimacy on education affairs like UNESCO (AUCC et al 2001, Rodrigues Dias 2002).

GATS defenders argue that the Agreement is necessary to attract education investment to poorer countries. However, critics maintain that international aid or foreign debt relief, but not trade, should be the main external mechanisms for increasing the education opportunities in developing contexts. In other words, international cooperation should be given priority over international trade in the education field because the latter are profit-oriented and not necessarily interested in 
promoting development. As the representative of a big international NGO stated in a social forum on GATS:

Even with a fairly small increase in Official Development Assistance (ODA) it would be possible to get everyone into school [...]. ODA should be increased to meet these global social spending goals and that it is the best possible use of ODA. We do not accept that the only way to get kids into school is to let the private sector invest in education. (Jobbs 2002, 3)

\section{b) Reformist proposals}

Rather than taking education out of the WTO, a second group of actors suggests that, to prevent the GATS from undermining education quality and education as a social right, the trade agreement should be subordinated to state education regulations and to international education conventions, such as the UNESCO conventions on recognition (Bergan 2002). In this line, a widely distributed public statement about GATS signed by university associations proposed that: a) trade should not be allowed to undermine the efforts of countries when it comes to develop their own education systems; b) national education authorities should retain the ability to regulate domestic education systems (AUCC et al 2001).

Another group of reformist proposals have a procedural focus on the way the agreement is being negotiated. For instance, one such proposal calls for the more active incorporation of the education community within the GATS negotiations, including more extensive consultation with education stakeholders by national trade negotiators (COL/UNESCO (2006). Other observers argue that the WTO should create a formal consulting body in which teachers unions would be represented, similarly to the trade union advisory committee to the OECD (Sánchez 2005). 
Another proposal aims to balance WTO members' negotiating power and resources by providing delegations from poorer countries with additional resources so that they can participate in the negotiations under conditions comparable to those of rich countries (Rodrigues Dias 2002). Finally, there are those that call for a moratorium on the trade in services negotiations and recommends that the negotiations are not taken up again until the effects of the GATS in the education field have been properly evaluated.

\section{c) Continuity}

According to GATS advocates, education liberalization under the agreement should continue and no central aspects of the current situation should be changed. It is not surprising that the WTO member countries with greater interests in trade in education services (such as New Zealand, the US or Australia) are the main proponents of the continuity and even of the intensification of the liberalization negotiations.

Australia currently enjoys the benefits of having a relatively open education and training regime. This openness is reflected in the significant number of commitments that Australia has entered in its current GATS schedule for the following educational services: secondary education, higher education and other education services. Australia believes that all Members should, in the context of the current round, consider entering commitments on education services similar to those already entered by Australia. This particularly applies to those Members who have previously failed to enter any commitments in relation to education services. (WTO-Australia 2001, 3) 
Some observers support the continuity of the GATS negotiations and the expansion of liberalization commitments, but consider that higher levels of "education reflexivity" should be contemplated into the negotiation and decision-making process. In other words, countries should take into account the necessities and interests of their national education systems when liberalizing education in the context of the WTO (Saner and Fasel 2003).

\section{The semiotics of the GATS and education debate}

Within the framework of the analyzed debate, two lines of argument are distinguished, one being very critical of the GATS while the other clearly supportive. When looking at the publication dates of the analyzed documentation, it emerges that GATS critics initiated the debate and GATS defenders reacted to the criticism. Furthermore, without the input of these critics, most pro-GATS arguments would have never crystallized publicly since their raison d'être consists of trying to refute the opposing side's arguments. This was acknowledged in the 'First OECD Forum on Trade in Education Services', which brought together trade representatives, education ministries, university associations, etc., the minutes of which state "advocates of GATS spent much of this forum talking about what it would not do in the education field" (Hirsch 2002, 9).

Both types of discourse are mainly based on hypotheses concerning the potential impact of the GATS on education systems, whether positive or negative. Statements based on empirical evidence are rare. On occasion, arguments are based on analogies with the liberalization experience in other sectors or with the education liberalization experience under regional trade agreements (see, for instance, Aboites 
2004 and Rodríguez Gómez 2004 with respect to NAFTA and its effects on the Mexican higher education system).

Most of the issues at stake are addressed from a causal or theoretical perspective. Nevertheless, the debate is grounded in principle and political beliefs about what education should (or should not) be for and how educational services should (or should not) be organized and provided. This distinction is important because principled beliefs are more difficult to "refute" than causal beliefs, which is something that reduces the possibilities of reaching some kind of consensus in the context of the debate and, at the same time, explain what the GATS and education debate is so passionate. Most critics problematize the inherent commodification of education that the trade agreement contributes to. They denounce that the WTO is reducing education to the level of a commodity that is sold and bought on an international scale. Therefore, they consider the fact itself that education is being negotiated within a trade agreement as problematic. For instance, for Education International, "the very fact that the education sector is now included in the discussions on trade liberalization is in itself alarming" (IE and PSI, 1999, 13).

\section{Language barriers and rhetoric strategies}

Most of the time, the participants of the debate are not neutral observers and are personally committed to their positions. Vlk (2006) observes that the GATS debate is very "emotional" due to the fact that the education community rejects the application of trade terminology to education issues. Following this author, the trade language makes it difficult for many education stakeholders to participate in the debate or to address some technical aspects, which is something that makes their reaction against GATS especially "emotional". Accordingly to him "what is not entirely understood 
might be perceived as potentially dangerous" (Vlk 2006: 145). Very often, trade experts also delegitimize the criticism to GATS by accusing critical educators of "misunderstanding" the trade agreement. This message is clearly emphasized in texts such as "GATS: Facts and Fiction," issued by the WTO, or in Sauvé (2002), who is a trade specialist from the OECD. It should be acknowledged, however, that some of the anti-GATS arguments are technically and analytically sophisticated. My analysis shows that, in occasions, rather than in misunderstandings, they indulge in hyperbole (or exaggeration), ${ }^{5}$ or mix the direct and indirect effects of GATS in their narratives in a way that overemphasizes the power of the agreement (for instance, by attributing to GATS effects coming from an increasing number of trade in education international flows, to which the GATS might only contribute indirectly).

The GATS supporters' arguments are even more problematic at the level of empirical credibility since they often resort to fallacious rhetorical strategies. The very fact itself that they consider that anti-GATS arguments are based on 'misunderstandings' is a secundum quid fallacy (i.e. taking part of the arguments of the opponents as the whole) (see types of fallacies in Lumer 2000).

Moreover, GATS supporters respond to criticism by saying that the trade agreement will have no negative effects for education due to its flexibility (i.e. countries are free to decide whether they adopt liberalization commitments in the context of the negotiations). As shown below, this argument is grounded on an ignoratio elenchi fallacy because reaches a conclusion by omitting essential elements in the argumentation chain. Specifically, there are three main omitted elements within

\footnotetext{
${ }^{5}$ For instance, the hyperbolic approach to the GATS can be clearly perceived in the following quotation: [Because of GATS] the education policies, the content of the programs and the validity of the certificates will not be fixed by governments, but by supra-national entities controlled by big corporations (...). Under the GATS scope, the state will not be able to define what and how to teach because any state intervention, such as the funding of public universities, will be perceived as a trade barrier. (Sánchez 2005, 35)
} 
the flexibility argument. First, the voluntary decision to adopt liberalization commitments in negotiation areas of GATS such as National Treatment or Market Access does not mean that there are no other implications associated with ratifying the Agreement (I refer to general obligations such as the Most Favored Nation or to the Domestic Regulation article). Second, flexibility in certain areas of the GATS negotiations does not offset the potential impact of education liberalization. In this sense, the "flexibility" argument works as a kind of rhetorical shortcut that posits that 'GATS does not have negative effect because countries are free to not subscribing commitments within the agreement'. What are, however, the implications of the agreement once liberalization commitments have been subscribed to? This question is often omitted in pro-GATS texts. Third, the idea of flexibility itself also needs to be problematized; research on the topic shows that countries - and in particular developing countries - are not so free to subscribe education commitments as the formal rules of the WTO presuppose. In many occasions, they have to liberalize education as conditionality to WTO membership or to get market access in other sectors (Verger 2008).

Finally, it should be acknowledged that GATS supporters usually justify their arguments by referring to the preamble of the Agreement, which is plenty of good declarations and principles. However, to contest the critiques, they barely refer to specific articles of the GATS, which are those that have direct legal implications in the signatory countries. In this case, GATS advocates would be resorting to an ad verecundiam fallacy that attributes veracity to an argument simply due to the authority of the agent that backs it.

Trade vs. education semiotic orders 
When the origin of the transmitters within the GATS education debate is analyzed, the first noteworthy result is that critics come from the education field (education experts and scholars, university associations, teachers' unions, UNESCO staff, among others) $^{6}$, while the GATS supporters come mostly from the trade field (WTO staff, trade negotiators, OECD trade division staff, trade scholars and so on). This shows very clearly that the two opposing semiotic orders identified in the GATS debate are directly linked to two very different social and institutional orders. The first semiotic order is linked to the education community and principally frames and disseminates the critical interpretations concerning GATS and its negative impact on education. The second order is embedded in the commercial world and frames the arguments concerning the positive effects of the Agreement.

Usually, the education and commercial sectors have their own dynamic and are mutually independent. Their representatives do not normally do business together (or are even in contact) and the topics they deal with, as well as their spheres of influence, are very distant from each other. Their technical jargon, their lexicon and even the meaning they give to the same words can be very different as well. However, the emergence of GATS has prompted these actors to interact, even though they approach to the topic from very different rationales and academic disciplines. Beyond the lack of shared language/jargon (Bassett 2006), the trade field and the education field are usually governed, in semiotic terms, by very different cognitive frames, principles and rationales. The prevailing frames in each field act as internal logical structures and devices of meaning production that clearly condition the way actors explain the world and, accordingly, the way they act. For this reason, education and

\footnotetext{
${ }^{6}$ This does not mean that the education community is always against the commodification or the introduction of market rules within education systems, but all critical texts identified come from the educational field.
} 
trade stakeholders construct and organize very different meaning repertoires with respect to the GATS and education debate. Furthermore, for this very same reason, in occasions, they do not necessarily understand each other or do not tolerate each other's approach to the GATS issue.

The anti-GATS discourse is clearly framed by a political commitment to education's traditional functions and, in most cases, by the idea of education as a public good and a human right. In the education field, the principles and values concerning the functions of education (for instance, its contribution to critical citizenship or economic development) and ideas on how education should be delivered (normally, through a strong state intervention and control) act as filters that contribute to reaching a common understanding over the GATS/education relationship. Additionally, education sector representatives' discourse on GATS issues is also shaped by the perception that trade representatives and rationales are "colonizing" the education sector. These factors largely explain why education stakeholders are deeply critical with the agreement.

For its part, the trade field is governed by a very different set of principles, causal beliefs and notions. The trade sector's semiotic order is constituted by the premises of the liberal theory of trade and the principle of comparative advantage, which says that "countries prosper first by taking advantage of their assets in order to concentrate on what they can produce best, and then by trading these products for products that other countries produce best", which, at the same time, will contribute to "sharpen competition, motivate innovation and breed success" (WTO 2005, 13). The trade community applies this frame to develop an understanding of the effects of education liberalization within the GATS and, when doing so, do not distinguish between the particularities of education and those of other very different sectors such 
as agriculture, textiles or mining. Therefore, assumptions on the positive relationship between international competition, efficiency and client satisfaction prevail in the interpretation of the benefits of the GATS for the education sector. At the same time, these strong theoretical assumptions set a shadow over the potential problems of the trade agreement - such as those that are precisely identified by the education community.

\section{Conclusions}

This article has analyzed the semiotics of the GATS and education debate at different levels. First, it has done so by understanding discourse as discursive practice, which implies focusing on the causal and principled beliefs that constitute the arguments pro and against GATS. In this respect, the debate on the potential costs and benefits of GATS for education covers issues such as national sovereignty, education quality, processes of development and privatization. This debate has been initiated by education stakeholders (university associations, teachers unions, education scholars, etc.) with critical positions on the topic, who suggest that education should be out of GATS or that, at least, this trade agreement should be reformed to become more respectful with the specificities of the education sector. Their criticism has been responded by a range of actors, most of them coming from the WTO system and likeminded organizations such as the OECD and the World Bank, that support that freetrade can benefit education systems all around the planet.

Second, I have applied CDA from the perspective of discourse as text, i. e. by looking at the linguistic features and rhetoric figures deployed by the participants in the debate. Among other things, I have observed that the actors involved in the debate resort to rhetoric strategies such as hyperbole (mostly in the case of education 
stakeholders) and different forms of fallacy (as in the case of trade stakeholders) to reinforce their positions.

Finally, I have applied CDA by looking at discourse as social practice or, in other words, by looking at the institutional orders in which the discourses on GATS are inscribed. In the 'GATS and education' debate, totally opposed ideas on the costs and benefits of free-trade for education are confronted. This ideational conflict can be partially attributed to different political and ideological preferences. However, I also argue that the different understandings of the GATS and education relationship are the consequence of the fact that most participants in the discussion come from two divorced semiotic and institutional orders. To a great extent, the divide between the trade and education semiotic and institutional orders, which has its roots in lexical and semantic, but more importantly, in principled and causal beliefs (i.e. education as a public good $v s$ free-trade theory), shapes the content and form of the debate and contributes to explain its polarization.

Future research should look in more detail at the recent evolution, in terms of content and composition, of the GATS and education debate. It should also look at the actual effects of the "battle of ideas" on the GATS and education relationship for the outcomes of the Doha Round. This type of study could feed a broader and evolving research line on the constitutive power of discourse or, in other words, on the role and impact of policy ideas and epistemic communities in local and global education politics. $^{7}$

\footnotetext{
${ }^{7}$ See contributions to this upcoming research area in Ball (2007), Jessop et al. (2008), Mundy (2007), Resnik (2006), Robertson (2005), Schriewer (2003), Steiner-Khamsi (2004) and Verger (forthcoming).
} 


\section{Bibliography}

Aboites, H. 2004. Derecho a la educación o mercancía: La experiencia de diez años de libre comercio en la educación mexicana. Memoria. Revista Mensual de Política y Cultura 187.

Altbach, P. G. 2002. Knowledge and Education as International Commodities: The Collapse of the Common Good. International Higher Education 28, 2-5.

—. 2004. Higher Education Crosses Borders. Change, March-April: 18- 24.

Anandakrishnan, M. 2004. Internationalization of Higher Education: Policy Concerns. In Internationalization of Higher Education: Issues and Policy Suggestions. National Institute of Educational Policy and Administration, New Delhi, Jan 2000. p.79-81.

AUCC, ACE, EUA, and CHEA. 2001. Joint Declaration about HE and the GATS. http://www.aic.lv/ace/gats/jointdec.html

Ball, S. J. 2007. Education plc: understanding private sector participation in public sector education. New York: Routledge.

Bashir, S. 2007. Trends in international higher education: implications and options for developing countries. World Bank Education Working Paper Series 6: 1-98.

Bassett, R. M. 2006. The WTO and the University: Globalization, GATS, and American Higher Education. New York: Routledge.

Bergan, S. 2002. Notes on Developments in Higher Education in Europe. In First Global Forum on International Quality Assurance, Accreditation and the Recognition of Qualifications in Higher Education. UNESCO, Paris, 17-18/10/02.

Bhushan, S. 2006. Foreign Education Providers in India: Mapping the Extent and Regulation. London: OBHE.

Birtwistle, T. 2006. Higher education and the general [lack of] agreement on trade in services: from Doha to Hong Kong and beyond. Education and the Law 18, no. 4: 295-307.

Brown, G. M. 2005. Three 'Controversial' Virtual Universities: Lessons from the Australian 
Experience. London: OBHE.

Chanda, R. 2003. Social Services and the GATS: Key Issues and Concerns. World Development 31, no. 12: 1997-2011.

COL/UNESCO. 2006. Higher Education: Crossing Borders: A Guide to the Implications of the General Agreement on Trade in Services (GATS) for Cross-Border Education. Paris: Commonwealth of Learning/UNESCO.

Czinkota, M.R. 2006. Academic freedom for all in higher education: The role of the general agreement on trade in services. Journal of World Business 41: 149-160.

Devidal, P. 2004. Trading Away Human Rights? The GATS and the Right to Education: a legal perspective. Journal of Critical Education Policy Studies 2, no. 2.

EI. 2006. Nota sobre las disciplinas de reglamentación nacional y los servicios educativos en el marco del AGCS. June 22.

EI, and PSI. 1999. The WTO and the Millennium Round: What Is at Stake for Public Education? Common Concerns for Workers in Education and the Public Sector. Brussels: Education International.

EUA. 2002. The Bologna Process and the GATS negotiations. Geneva: European University Association.

Fairclough, N. 2003. Analysing Discourse. London: Routledge.

Fairclough, N., Jessop, B., and Sayer, A. 2004. Critical realism and semiosis. In J. Joseph and J. M. Roberts (Eds.), Realism Discourse and Deconstruction (pp. 23-42). London: Routledge.

Francois, J., and I. Wooton. 2000. Market Structure, trade Liberalisation and the GATS. Centre for International Economic Studies. Policy Discussion Paper, no. 3.

Fredriksson, U. 2004. Studying the Supre-National in Education: GATS, education and teacher union policies. European Educational Research Journal 3, no. 2: 415-441.

García-Guadilla, C. 2003. El difícil equilibrio. La educación superior como bien público y comercio de servicios. Caracas: Editorial Latina.

Garrett, R. 2005. Fraudulent, sub-standard, ambiguous the alternative borderless higher 
education. OBHE Briefing Note 24.

Gilpin, R. 1987. The political economy of international relations. Princeton: Princeton University Press.

van Ginkel, H. J. A., and M. A. Rodrigues Dias. 2006. Retos Institucionales y políticos de la acreditación en el ámbito internacional. In La Educación Superior en el Mundo 2007. Acreditación para la garantía de calidad: ¿Qué está en juego? Barcelona: MundiPrensa.

Grieshaber-Otto, J., and M. Sanger. 2002. Perilous Lessons. The Impact of the WTO Services Agreement (GATS) on Canada's Public Education System. Ottawa: Canadian Centre for Policy Alternatives.

Hirsch, D. 2002. Report of the GATS and education debate. OECD/US Forum on Trade in Educational Services (Washington, DC, U.S.A. 23 - 24 May 2002).

Jessop, B., N. Fairclough, and R. Wodak. 2008. Education and the Knowledge-Based Economy in Europe. Rotterdam: Sense.

Jobbs, J. 2002. Speaking notes for World Social Forum event "GATS and the future of public services” [Oxfam International]. World Social Forum, Porto Alegre, January 2002.

Kelsey, J. 2003. Legal Fetishism and the Contradictions of the GATS. Globalisation, Societies and Education 1, no. 3: 321-357.

Knight, J. 2007. Cross-border higher education: issues and implications for quality assurance and accreditation. In Higher Education in the World 2007. Accreditation For Quality Assurance: What Is At Stake?, 134-158. New York: Palgrave MacMillan.

Larsen, K., J. P. Martin, and R. Morris. 2002. Trade in Educational Services: Trends and Emerging Issues. The World Economy 25, no. 6: 849-868.

Larsen, K., and S. Vincent-Lancrin. 2002. International trade in educational services: good or bad? Higher Education and management Policy 14, no. 3: 2-45.

Lumer, C. 2000. Reductionism in fallacy theory. Argumentation 14 (4): 405-423.

Maroy, C. 2008. Convergences and hybridization of educational policies around 'postbureaucratic' models of regulation. Compare 39, no. 1: 71 - 84 
Mattoo, A., and R. Rathindran. 2001. Measuring Services Trade Liberalization and Its Impact on Economic Growth: An Illustration. Policy Research Working Paper. The World Bank, no. 2655.

Menashy, F. 2007. World Bank Education Policy: Do the neoliberal critiques still apply? McGill Journal of Education 42, no. 1: 47-60.

Mundy, K. 2007. Global governance, educational change. Comparative Education 43, no. 3 : $339-357$.

NEA. 2004. Higher Education and International Trade Agreements. An Examination of the Threats and Promises of Globalization. Washington: National Education Association.

OECD, and World Bank. 2007. Cross-border Tertiary Education. A Way Towards Capacity Development. Paris: OECD.

Parker, I. 1992. Discourse Analysis. Critical analysis for social and individual psychology. London: Routledge.

Pillay, P. 2003. The General Agreement on Trade in Services (GATS): Implications and Possible Ways Forward for the Southern African Development Community (SADC). In UNESCO Conference on Globalization and Higher Education. Oslo, 26-27 May 2003.

Poblano, J. F. 2004. Los Acuerdos de Reconocimiento Mútuo: La Experiencia de México en el TLCAN. In Seminario Internacional 2004. Movilidad Internacional de Profesionales: Condiciones para la Confianza Recíproca. Santiago: CSE/CNAP.

Resnik, J. 2006. International Organizations, the 'Education-Economic Growth’ Black Box, and the Development of World Education Culture. Comparative Education Review, 50, 2: 173-195.

Robertson, S. 2005. Re-imagining and rescripting the future of education: global knowledge economy discourses and the challenge to education systems. Comparative Education $41(2): 151-170$.

Robertson, S., X. Bonal, and R. Dale. 2002. GATS and the education services industry: the politics of scale and global reterritorialization. Comparative Education Review 46, no. 
4: $472-496$.

Rodrigues Dias, M. A. 2002. Some aspects of the impact of globalization in Higher Education on developing countries. In The Prometeus Conference. Paris, 29 September 2002.

Rodríguez Gómez, R. 2004. Inversión Extranjera Directa en Educación Superior. El caso de México. Revista Educación Superior 33, no. 2.

Rogers, R., E. Malancharuvil-Berkes, M. Mosley, D. Hui, and G. O.G Joseph. 2005. Critical discourse analysis in education: A review of the literature. Review of Educational Research 75 (3): 365.

Sánchez, H. 2005. Tratados comerciales y de inversión: su impacto en la educación. In Acuerdos Comerciales y Educación. San José: IE-AL.

Saner, R. 2008. The expert negotiator: strategy, tactics, motivation, behaviour, leadership. Leiden: Brill.

Saner, R, and S. Fasel. 2003. Negotiating Trade in Educational Services within the WTO/GATS context. Aussenwirtschaft 11: 257-308.

Santos, B. S. 2004. La Universidad del siglo XXI. Para una reforma democrática y emancipadora de la Universidad. Buenos Aires: Miño y Dávila.

Sanyal, B. C., and M. Martin. 2005. La financiación de la educación superior: perspectiva internacionales. In La Educación Superior en el Mundo 2006. La financiación de las universidades. Barcelona: Mundi-Prensa.

Sauvé, P. 2002. Trade, Education and the GATS: What's In, What's Out, What's All the Fuss About? Higher Education Management and Policy 14, no. 3: 1-30.

Scherrer, C. 2007. GATS: commodifying education via trade treaties. In New Arenas of Education Governance: The Impact of International Organizations and Markets on Educational Policy Making. London: Palgrave.

Schriewer, J. 2003. Globalisation and education: Process and discourse. Policy Futures in Education, 1(2), 271-283.

Steiner-Khamsi, G. 2004. The global politics of educational borrowing and lending. New York: Teachers College. 
Taylor, S. 2004. Researching educational policy and change in 'new times': using critical discourse analysis. Journal of Education Policy 19 (4): 433-451.

Tomasevski, K. 2005. Globalizing What: Education as a Human Right or as a Traded Service? Indiana Journal of Global Legal Studies 12, no. 1: 1-78.

Verger, A. 2008. Measuring Educational Liberalisation. A Global Analysis of GATS. Globalisation, Societies and Education 6, no. 1: 13-31.

Verger, A. Forthcoming. Framing and selling global education policy: The promotion of public-private partnerships for education in low-income contexts. Journal of Education Policy.

Verger, A., and X. Bonal. 2009. Education vs Trade: Global Struggles Challenging WTO/GATS. In Contesting Neoliberal Education: Public Resistance and Collective Advance, 181-201. New York: Routledge.

Vlk, A. 2006. Higher Education and GATS. Regulatory Consequences and Stakeholders' Responses. University of Twente: CHEPS.

Williams, S. 2003. UNESCO in action education: Borderless Education. The New Courier 2.

WTO. 1994. Agreement stablishing the World Trade Organization. In http://www.wto.org/english/docs_e/legal_e/legal_e.htm\#finalact [last retrieved: 18/06/11]

- 2001. GATS- fact and fiction. Geneva: World Trade Organization.

. 2002. Director-general of WTO and chairman of WTO services negotiations reject misguided claims that public services are under threat. WTO NEWS: 2002 PRESS RELEASES Press/299 28 June 2002.

WTO-Australia. 2001. Communication from Australia. Negotiation Proposal for Education Services. http://www.wto.org/English/tratop_e/serv_e/s_propnewnegs_e.htm.

WTO-NZ. 2001. Communication from New Zealand. Negotiation Proposal for Education Services. http://www.wto.org/English/tratop_e/serv_e/s_propnewnegs_e.htm.

WTO. 2005. Understanding the WTO. Geneva: WTO. 